\title{
Evaluation of Tactics for Management of Thrips-Vectored Tomato spotted wilt virus in Tomato
}

\author{
D. G. Riley, Department of Entomology, H. R. Pappu, Department of Plant Pathology, University of Georgia, \\ Coastal Plain Experiment Station, Tifton 31793
}

\begin{abstract}
Riley, D. G., and Pappu, H. R. 2000. Evaluation of tactics for management of thrips-vectored Tomato spotted wilt virus in tomato. Plant Dis. 84:847-852.

Two studies were conducted in Georgia during the spring of 1997 and 1998 to evaluate various management practices for reducing thrips and thrips-vectored Tomato spotted wilt virus (TSWV) in tomato. Populations of the two species of thrips responsible for transmitting TSWV in tomato fields, Frankliniella occidentalis and $F$. fusca, were determined using blossom and sticky trap samples. Management practices evaluated were host plant resistance, insecticide treatments, planting date, and light-reflective mulch. In both years, intensive insecticide treatment had the largest effect in reducing thrips and spotted wilt and increasing marketable yield, compared with host plant resistance and reflective mulch. The effect of planting date was consistent in that the later planting date resulted in higher incidence of TSWV, lower thrips numbers, and lower tomato yields, both in fruit quality and dollar value. Host plant resistance and reflective mulch significantly reduced thrips and TSWV. In both years, early planting on black plastic with an intensive insecticide treatment resulted in the highest yield.
\end{abstract}

Additional key words: ELISA, host plant resistance, reflective plastic mulch, thrips control, tobacco thrips, western flower thrips

Thrips-vectored Tomato spotted wilt virus (TSWV) is one of the major factors contributing to yield loss in tomato (Lycopersicon esculentum) in Georgia, affecting approximately $25 \%$ of this crop, valued at $\$ 44$ million (10). Also, this virus has become a major yield-limiting factor to production of many other crops in Georgia, including pepper, peanut, and tobacco, with total losses estimated at $\$ 100$ million in $1996(1,14)$. TSWV is one of the most economically important members of the genus Tospovirus (family Bunyaviridae) $(11,12,15)$. TSWV is transmitted by multiple species of thrips (24). Thrips responsible for spotted wilt epidemics in Georgia and Florida can be largely attributed to western flower thrips, Frankliniella occidentalis; tobacco thrips, $F$. fusca; and $F$. bispinosa $(18,23,25$, respectively). In general, immature thrips in the first and second instars acquire TSWV from infected host plants, the virus replicates in the vector as it matures, and subsequently viruliferous adults spread the virus when they

Corresponding author: D. G. Riley

E-mail: driley@tifton.cpes.peachnet.edu

Grant support was provided in part by the USDA Southern Region IPM Grant \# 98-34103-6268 and the Georgia Agricultural Experiment Stations.

Accepted for publication: 20 April 2000.

Publication no. D-2000-0530-01R

(C) 2000 The American Phytopathological Society move to other plants. Virus multiplication in the thrips vector makes managing TSWV difficult because, once infected, adults thrips can migrate long distances to new host plants and quickly transmit the virus before thrips can be controlled (24).

Due to the severity of TSWV and difficulty in preventing thrips transmission with any single control tactic, such as insecticide treatment, an integration of multiple control tactics has been recommended as the best approach (4). A TSWV risk index has been developed for peanut in Georgia based on multiple management factors (2). However, no such information has been formally developed for managing TSWV in tomato. Several control tactics are available, including the use of reflective plastic mulch $(3,6,22)$, host plant resistance $(8)$, and, potentially, insecticides $(5,7)$. The simultaneous evaluation of multiple control tactics for thrips and tomato spotted wilt management in tomato has not been reported. We investigated host plant resistance, planting date, thrips management practices, and reflective plastic mulch for developing an integrated management program for TSWV control in tomato. The objective was to determine the best combination of tactics for managing thrips and TSWV in tomatoes.

\section{MATERIALS AND METHODS}

The first study was conducted in 1997 at the Coastal Plain Experiment Station, Tifton, GA to evaluate an intensive insecticide treatment, a TSWV-resistant tomato cultivar, a reflective plastic mulch, and two planting dates. The tomato production system used was raised black plastic beds fumigated with methyl bromide $(277 \mathrm{~kg}$ a.i./ha, Albemarle Corp., Magnolia, AK) with plants staked and tied at 0.6-m spacing in a single row. A split-plot design with four replicates was used. The two main plots were (i) cv. Stevens (TSWV-resistant cultivar, source: J. Scott, Gulf Coast Research and Education Center, Bradenton, FL) and (ii) cv. Sunny Hybrid (TSWVsusceptible hybrid, Asgrow Seed Company, Tifton, GA) tomato. The subplots consisted of various planting date, insecticide, and mulch treatment combinations, as follows: (i) early planted (7 April), untreated, black plastic; (ii) early planted, insecticide, black plastic; (iii) early planted, untreated, silver plastic; (iv) early planted, insecticide, silver plastic; (v) early planted, untreated, bare ground; (vi) early planted, insecticide, bare ground; (vii) late planted (7 May), untreated, black plastic; (viii) late planted, insecticide, black plastic; and (ix) late planted, insecticide, silver plastic. The insecticide treatment consisted of a soil treatment of phorate (Thimet 15 Granular, American Cyanamid, Wayne, $\mathrm{NJ})$ at 68 grams per 100 meters of row at transplant plus foliar sprays of spinosad (Spintor 2 Soluble Concentrate [SC], Dow AgroSciences, Indianapolis, IN) at $0.1 \mathrm{~kg}$ a.i./ha and chlofenapyr (Alert 2 SC, American Cyanamid, Wayne, NJ) at 0.17 kg a.i./ha on 29 April; 6, 14, and 22 May; 3,12 , and 26 June; and 3 and 12 July. The exposed black plastic mulch (1.25 mil, North American Film, Philadelphia) was painted with silver aluminum paint (Super Brite, Sherwin Williams, Cleveland) in the silver treatment plots. The silver paint reflected a wide range of visible light (three to five times that of the unpainted black plastic mulch and approximately $34 \%$ of a mirror standard) using a standard reflectance analysis (S2000 Miniature Fiber Optic Spectrometers and Accessories, Ocean Optics, Inc., Dunedin, FL). The bare ground plots had the plastic mulch removed at the time of transplanting.

The thrips parameters measured were total numbers and numbers of certain target species using two different sampling methods. Ten blossoms, one blossom per plant, were randomly collected and placed into a vial with a $50 \%$ ethanol solution per plot on a weekly basis. Also, sticky cards (one yellow and one blue, 7.6 by $12.7 \mathrm{~cm}$, Ol- 
son Products, Medina, OH) were placed vertically on a wooden stake $8 \mathrm{~cm}$ above the soil to the bottom of the trap in the center of each plot for 1 week. Cards were then collected into clear plastic bags, and thrips were counted per $96.5 \mathrm{~cm}^{2}$ area. Adult thrips in both the blossom samples and sticky card samples were identified using identification keys $(13,17,21)$ under $\times 70$ to 140 magnification using a SZH10 Olympus (Olympus America, Lake Success, NY) stereomicroscope. In the sticky trap and blossom samples, only $F$. occidentallis and $F$. fusca were individually counted; all other thrips, including $F$. tritici, F. bispinosa, and others, were placed into an "other" category. From these samples, a subset of thrips were slide mounted for voucher specimens. Key characters were used to verify species, including the anteromarginal and anteroangular setae, postocular setae, the pedicel of the third antennal segment, comb on abdominal tergite VIII, and other features. Other insects were monitored in the trial, but the incidence of other pest species, such as potato aphid (Macrosiphum euphorbiae), southern armyworm (Spodoptera eridania), and others was very low in both years.

Characteristic TSWV-induced symptoms on tomato include necrotic lesions that often coalesce and spread to the rest of the leaf or result in veinal necrosis. Early infection almost always results in stunting of the plant. Disease incidence was monitored by counting the number of symptomatic plants per plot on a weekly basis and taking leaf samples for enzyme-linked immunosorbent assay (ELISA). A single, fully expanded terminal leaflet was randomly collected from the top third of a tomato plant from each experimental plot to detect TSWV by ELISA. In 1997, this sample was taken 1 week before harvest from 1 symptomatic and 1 asymptomatic plant per 17-plant plot $(n=144)$. In 1998, samples were randomly collected and tested from each plot on 26 March; 8, 15, and 29 April; and 1, 15, 21, and 28 May ( $n$ =396). On 10 June and 7 July, 1 symptomatic and 1 asymptomatic plant were sampled per 20-plant-plot near harvest from early and late planted tomato plants $(n=$ 288), respectively, as was done in 1997. The incidence of TSWV infection in these samples was determined by ELISA using a TSWV detection kit (Agdia Inc., Elkhart, IN). A sample was deemed positive for TSWV if the absorbance reading was three times the value of a known uninfected sample.

Yield was assessed by quantifying fruit in various damage categories and a mar- ketable category at the time of harvest. Insect damage to the fruit consisted of thrips dimpling of fruit, which was considered still marketable if the fruit had acceptable shape and color, and Lepidopteradamaged fruit (negligible in these tests). In general, physiological fruit damage, blotchy-colored fruit, and blossom end rot resulted in fruit being culled. Irregularly ripened or blotchy-colored fruit at the time of harvest were assumed to be due to TSWV because the other potential causes, such as whiteflies, were virtually absent during these tests in both years. In 1998, a subsample of 10 medium-size, green fruit from each plot was held in paper bags for 2 weeks and the percentage of completely regularly ripened fruit was recorded. For marketable yield, the approximate value of the crop was estimated per acre using $\$ 7$ per 11.3-kg (25-lb) carton of marketable fruit and a tomato plant population of 4,356 plants per 0.4 ha (acre). Analysis of variance was conducted using Proc GLM (19), and separation of means at the subplot level was determined using least significant difference (LSD) tests and contrast analysis for early versus late planted, insecticide-treated versus untreated, and silver versus black plastic mulch.

In 1998, a similar study was conducted based on the 1997 results, except a split-

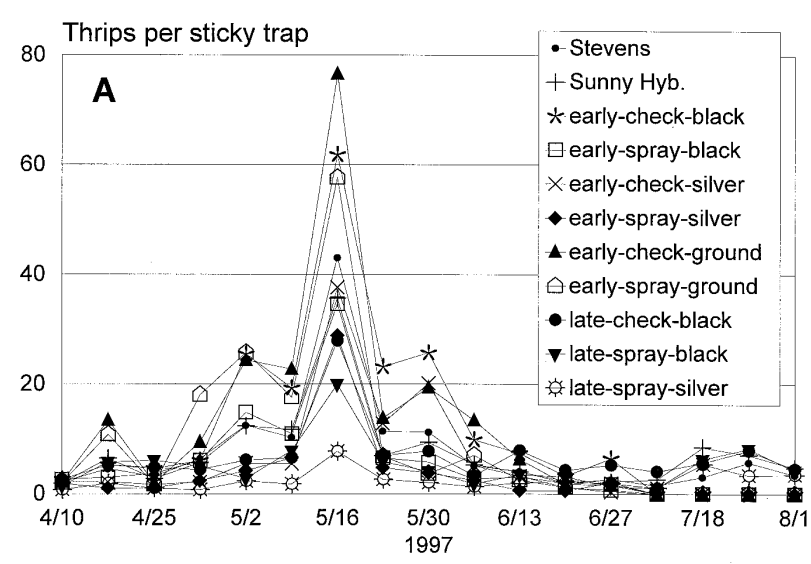

Sampling date

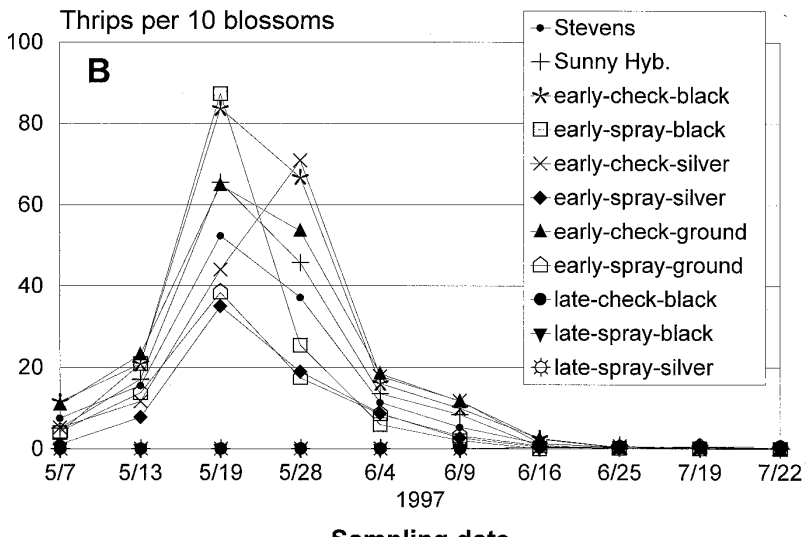

Sampling date

Fig. 1. Total thrips per subplot treatment (A) per sticky card and (B) per 10 tomato blossoms by date at Tifton, GA in the spring of 1997.
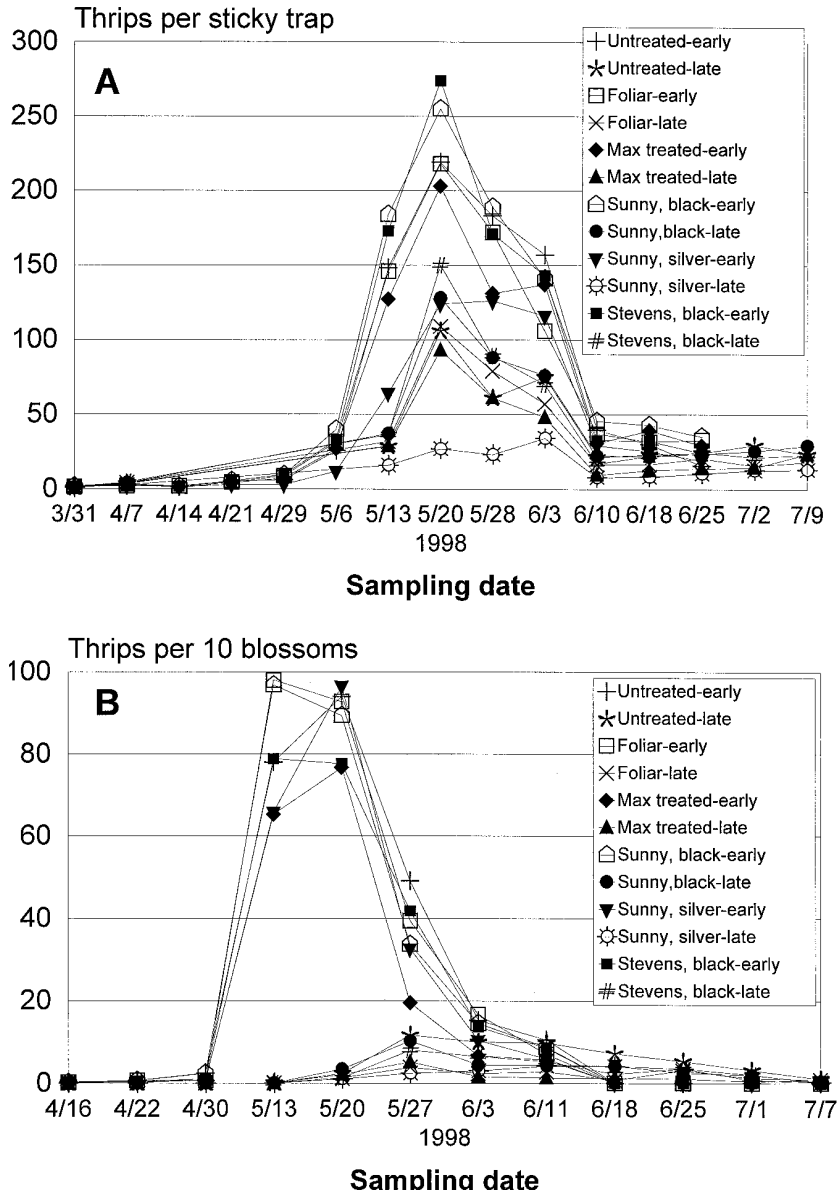

Fig. 2. Total thrips per sub- and sub-subplot treatments (A) per sticky card and (B) per 10 tomato blossoms by date at Tifton, GA in the spring of 1998 . 
split plot design was used and treatments were arranged to maximize the use of this design. The split-split plot design with four replications was as follows. Main plots consisted of two transplant dates, 24 March or 4 May. Subplots were three insecticide treatments: (i) untreated; (ii) weekly foliar treatments only of $\lambda$-cyhalothrin (Karate 1 Emulsifiable Concentrate, Zeneca Ag Products, Wilmington, DE) at $0.017 \mathrm{~kg}$ a.i./ha and methamidophos (Monitor 4 Liquid, Bayer Corp., Kansas City, MO) at $0.84 \mathrm{~kg}$ a.i./ha rotated with spinosad (Spintor $2 \mathrm{SC}$ ) at $0.1 \mathrm{~kg}$ a.i./ha; and (iii) a soil treatment of imidacloprid (Admire $2 \mathrm{~F}$, Bayer Corp., Kansas City, MO) at $0.17 \mathrm{~kg}$ a.i./ha (drench of $0.067 \mathrm{ml}$ of Admire $2 \mathrm{~F}$ in $104 \mathrm{ml}$ of water at the base of each plant based on 4,356 plants per 0.405 ha [acre] at transplant) followed by $\lambda$-cyhalothrin at $0.017 \mathrm{~kg}$ a.i./ha plus methamidophos at $0.84 \mathrm{~kg}$ a.i./ha rotated with spinosad at 0.1 $\mathrm{kg}$ a.i./ha, each applied weekly or as two sprays per week. These treatments are registered for use on tomato and are effective for thrips control (D. G. Riley, unpublished data). Sub-subplot treatments consisted of three tomato cultivar and plastic mulch combinations: (i) cv. Sunny Hybrid on black plastic, (ii) Sunny Hybrid on silvered plastic, and (iii) cv. Stevens on black plastic. The parameters measured were the same as in 1997, except for additional weekly random samples assayed by ELISA. The number of observations $(n)$ for calculating percentages of thrips species was based on all samples where thrips were present. Analysis of variance was conducted using Proc GLM (19) and separation of treatments means at the sub and sub-subplot levels was determined using LSD tests.

\section{RESULTS AND DISCUSSION}

Total numbers of thrips within tomato blossoms and on sticky cards were similar in 1997 (Fig. 1) and 1998 (Fig. 2), both peaking at the second to third week in

\section{F. occidentalis per 10 blossoms}

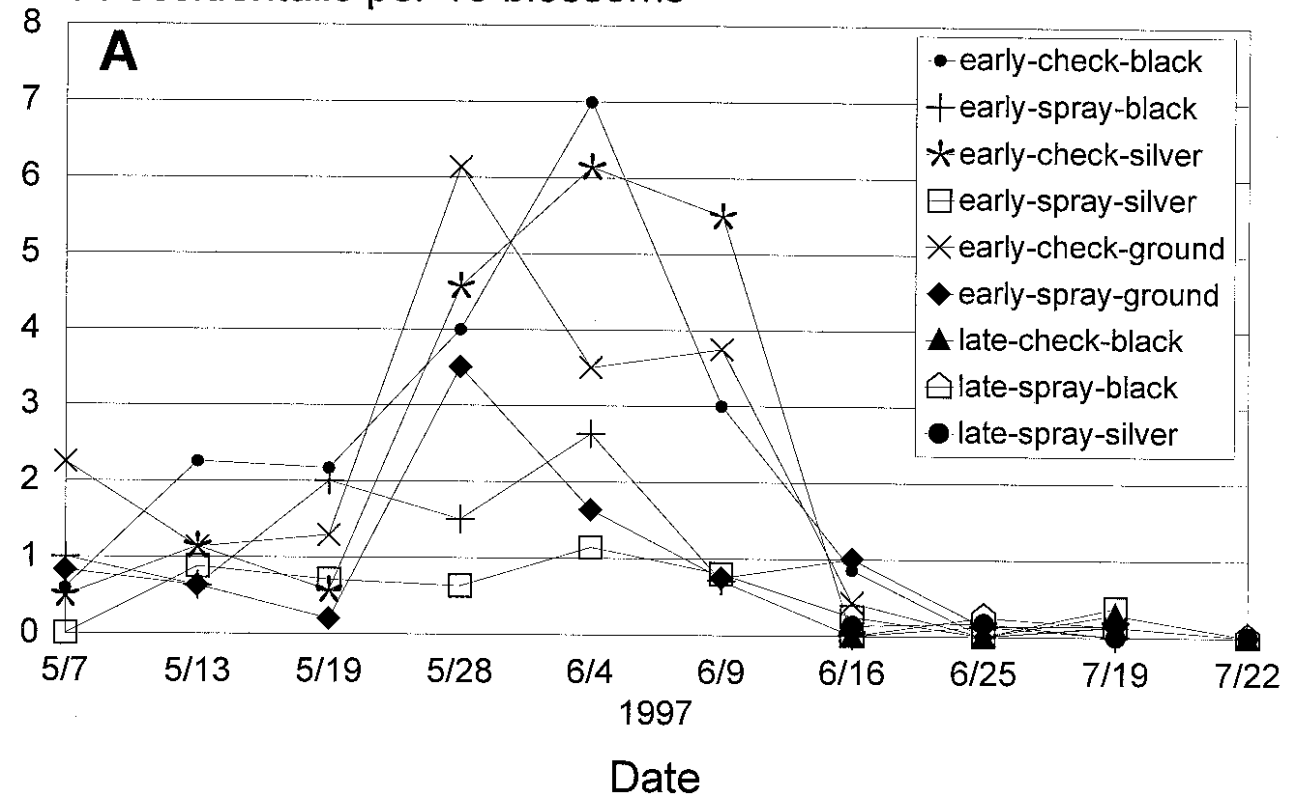

\section{F. occidentalis per 10 blossoms}

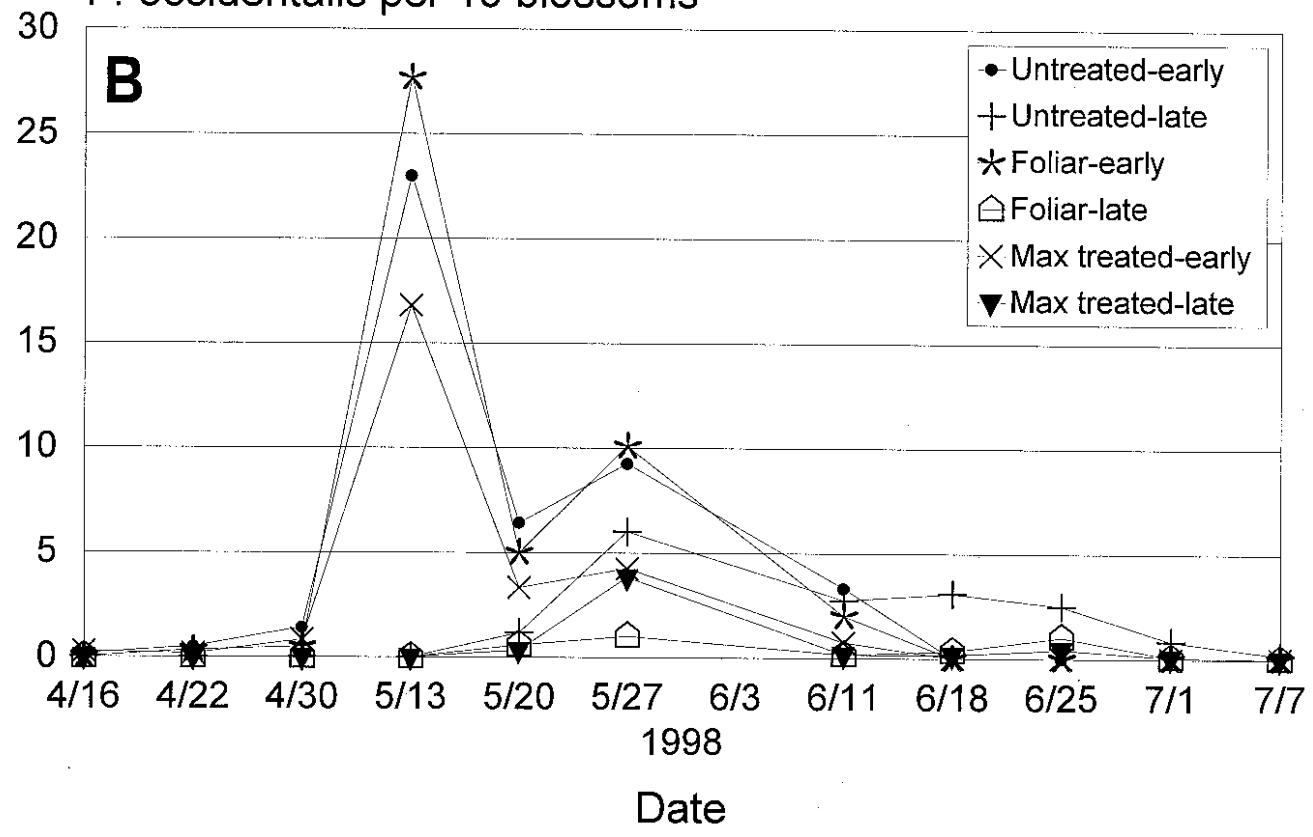

Fig. 3. Number of Frankliniella occidentalis per treatment per 10 tomato blossoms at the subplot level in (A) 1997 and (B) 1998 by date at Tifton, GA. 
May, which was also similar to the results of Salguero-Navas et al. (18) in north Florida. Of the individual species counted in the 1997 and 1998 trials, F. occidentalis represented $25 \pm 2 \%$ (STDERR, $n=263$ ) and $31 \pm 2 \%(n=365)$, respectively, and $F$. fusca represented $2 \pm 0.7 \%(n=263)$ and 7 $\pm 1 \%(n=365)$, respectively. $F$. occidentalis was a predominant TSWV-vector species counted in the blossom sample in both years (Fig. 3) and was positively correlated with damaged fruit in $1997(R=0.25, n=$ $143, P=0.003)$ and negatively correlated with total number of tomato fruit per fiveplant harvest in $1998(R=-0.19, n=144$, $P=0.02)$. These data suggest that $F$. occidentalis was an important TSWV vector in this tomato production system, similar to a previous report (18). Prebloom thrips populations on the plant were not quantified. Sticky card samples provided some measure of thrips activity before bloom (Figs. 1 and 2). F. occidentalis represented $28 \pm 2 \%$ (STDERR, $n=273$ ) and $1 \pm 0.4 \%$ $(n=392)$ and $F$. fusca represented $12 \pm 1 \%$ $(n=273)$ and $2 \pm 0.5 \%(n=392)$ in the first four weekly samples taken before 1 May, when the plants were at early bloom stage, in 1997 and 1998, respectively. These data show that both $F$. fusca and $F$. occidentalis can occur in significant numbers in a tomato field before the bloom stage.

The maximum reduction of the seasonal mean of total thrips per trap was $85 \%$ between early plant, untreated, black plastic and late planted, treated, silver plots in 1997 (Table 1). A 91\% reduction of thrips was observed between early planted black $($ mean $=46)$ and late planted silver plots $($ mean $=5)$ in 1998. Significant reductions in thrips numbers were observed in thrips per 10 blossoms between untreated and treated early treatments and between early and late treatments in 1997 (Table 1). Also, untreated and maximum treated plots and early and late treatments differed in 1998 (Table 2). These data suggested that planting date and insecticide treatments were particularly effective in reducing thrips numbers. The greatest reduction of thrips in tomato blossoms in 1997 was achieved with late versus early planting dates (late $=$ 3.1, early $=72.6$, df $=1, F=74.9, P=$ 0.0001 ), followed by insecticide treatment (treated $=25$, untreated $=50, \mathrm{df}=1, F=$ 24.6, $P=0.0001)$ and silver reflective mulch (silver $=20$, black $=29, \mathrm{df}=1, F=$ $3.75, P=0.06)$. Similar treatment effects on thrips numbers were observed in 1998 (Table 2).

In contrast to the thrips data, the overall incidence of TSWV was lower in early planted tomato than in late planted tomato

Table 1. Main plot (cultivar) and subplot (insecticide, mulch, and planting date) treatment effects on the seasonal average of total thrips in blossoms and on traps, Frankliniella occidentalis in blossoms, and incidence of Tomato spotted wilt virus (TSWV) based on enzyme-linked immunosorbent assay (ELISA) before harvest in 1997 at Tifton, GA ${ }^{\mathrm{w}}$

\begin{tabular}{|c|c|c|c|c|c|c|}
\hline \multirow[b]{2}{*}{ Treatment $^{\mathrm{x}}$} & \multicolumn{2}{|c|}{ Total thrips } & \multicolumn{2}{|c|}{ F. occidentalis } & \multirow[b]{2}{*}{ ELISA value ${ }^{y}$} & \multirow[b]{2}{*}{ Percent positive TSWV } \\
\hline & Per 10 blossoms & Per trap & Per 10 blossoms & Per trap & & \\
\hline \multicolumn{7}{|l|}{ Main plots } \\
\hline 'Stevens' & $7.7 \mathrm{a}$ & $9.5 \mathrm{a}$ & $0.99 \mathrm{a}$ & $1.25 \mathrm{a}$ & $0.30 \mathrm{a}$ & $25 \mathrm{a}$ \\
\hline 'Sunny Hybrid' & $9.1 \mathrm{a}$ & $8.5 \mathrm{a}$ & $1.05 \mathrm{a}$ & $0.97 \mathrm{a}$ & $0.17 \mathrm{a}$ & $17 \mathrm{a}$ \\
\hline \multicolumn{7}{|l|}{ Subplots } \\
\hline Early check black & $17.7 \mathrm{a}$ & $16.9 \mathrm{a}$ & $2.45 \mathrm{a}$ & $2.20 \mathrm{a}$ & $0.32 \mathrm{ab}$ & $25 \mathrm{a}$ \\
\hline Early check bare & $16.8 \mathrm{a}$ & $16.7 \mathrm{a}$ & $2.03 \mathrm{ab}$ & $2.08 \mathrm{a}$ & $0.21 \mathrm{~b}$ & $38 \mathrm{a}$ \\
\hline Early check silver & $13.1 \mathrm{ab}$ & $8.0 \mathrm{bc}$ & $2.02 \mathrm{ab}$ & $1.00 \mathrm{bc}$ & $0.27 \mathrm{ab}$ & $13 \mathrm{a}$ \\
\hline Early treated black & $10.6 \mathrm{bc}$ & $7.6 \mathrm{bcd}$ & $0.91 \mathrm{c}$ & $0.90 \mathrm{bc}$ & $0.06 \mathrm{~b}$ & $0 \mathrm{a}$ \\
\hline Early treated bare & $7.6 \mathrm{~cd}$ & $12.1 \mathrm{ab}$ & $1.01 \mathrm{bc}$ & $1.53 \mathrm{ab}$ & $0.17 \mathrm{~b}$ & $25 \mathrm{a}$ \\
\hline Early treated silver & $6.7 \mathrm{~cd}$ & $4.9 \mathrm{~cd}$ & $0.54 \mathrm{c}$ & $0.60 \mathrm{c}$ & $0.03 \mathrm{~b}$ & $0 \mathrm{a}$ \\
\hline Late check black & $2.8 \mathrm{de}$ & $7.1 \mathrm{bcd}$ & $0.07 \mathrm{c}$ & $0.77 \mathrm{bc}$ & $0.51 \mathrm{a}$ & $38 \mathrm{a}$ \\
\hline Late treated black & $0.2 \mathrm{e}$ & $5.3 \mathrm{~cd}$ & $0.09 \mathrm{c}$ & $0.63 \mathrm{c}$ & $0.26 \mathrm{ab}$ & $25 \mathrm{a}$ \\
\hline Late treated silver & $0.1 \mathrm{e}$ & $2.6 \mathrm{~d}$ & $0.06 \mathrm{c}$ & $0.24 \mathrm{c}$ & $0.22 \mathrm{ab}$ & $25 \mathrm{a}$ \\
\hline
\end{tabular}

${ }^{\text {w}}$ Means in columns followed by different letters significantly different using least significant difference tests $(P<0.05)$ within significant main plot and subplot treatment effects $(P<0.05)$.

${ }^{\mathrm{x}}$ Early $=$ transplanted 7 April, late $=7$ May, check $=$ untreated with insecticide, treated $=$ treated with insecticide, black $=$ black plastic mulch, bare $=$ bare soil, and silver $=$ silver-painted black plastic mulch.

y Analysis using ELISA values.

${ }^{\mathrm{z}}$ Analysis using number of ELISA-positive samples.

Table 2. Main plot (date) and subplot (insecticide) and sub-subplot (cultivar, mulch) treatment effects on the total number of thrips in blossoms and on traps, Frankliniella occidentalis in blossoms, and incidence of Tomato spotted wilt virus (TSWV) based on enzyme-linked immunosorbent assay (ELISA; during growing season and at harvest) in 1998 at Tifton, $\mathrm{GA}^{\mathrm{v}}$

\begin{tabular}{|c|c|c|c|c|c|c|c|}
\hline \multirow[b]{2}{*}{ Treatment $^{w}$} & \multicolumn{2}{|c|}{ Total thrips } & \multirow{2}{*}{$\begin{array}{c}\text { F. occidentalis } \\
\text { Per } 10 \text { blossoms }\end{array}$} & \multicolumn{2}{|c|}{ Season } & \multicolumn{2}{|c|}{ Harvest } \\
\hline & Per 10 blossoms & Per trap & & ELISA mean ${ }^{y}$ & TSWV $^{\mathrm{z}}$ & ELISA mean ${ }^{y}$ & TSWV $^{\mathbf{z}}$ \\
\hline \multicolumn{8}{|l|}{ Main plots } \\
\hline Early & $19.6 \mathrm{a}$ & $59.9 \mathrm{a}$ & $3.67 \mathrm{a}$ & $0.05 \mathrm{~b}$ & $9 \mathrm{~b}$ & $0.63 \mathrm{a}$ & $22 \mathrm{a}$ \\
\hline Late & $2.4 \mathrm{~b}$ & $32.2 \mathrm{a}$ & $0.83 \mathrm{~b}$ & $0.09 \mathrm{a}$ & $11 \mathrm{a}$ & $0.46 \mathrm{a}$ & $23 \mathrm{a}$ \\
\hline \multicolumn{8}{|l|}{ Subplots } \\
\hline Untreated & $12.7 \mathrm{a}$ & $50.2 \mathrm{a}$ & $2.83 \mathrm{a}$ & $0.07 \mathrm{a}$ & $12 \mathrm{a}$ & $0.58 \mathrm{ab}$ & $22 \mathrm{a}$ \\
\hline Foliar & $12.4 \mathrm{a}$ & $46.3 \mathrm{a}$ & $2.44 \mathrm{ab}$ & $0.07 \mathrm{a}$ & $8 \mathrm{a}$ & $0.68 \mathrm{a}$ & $27 \mathrm{a}$ \\
\hline Foliar + soil & $7.9 \mathrm{~b}$ & $41.6 \mathrm{a}$ & $1.47 \mathrm{~b}$ & $0.09 \mathrm{a}$ & $10 \mathrm{a}$ & $0.34 \mathrm{~b}$ & $18 \mathrm{a}$ \\
\hline \multicolumn{8}{|l|}{ Sub-subplots } \\
\hline Sunny + black & $12.0 \mathrm{a}$ & $57.1 \mathrm{a}$ & $2.44 \mathrm{a}$ & $0.08 \mathrm{a}$ & $10 \mathrm{ab}$ & $0.65 \mathrm{a}$ & $30 \mathrm{a}$ \\
\hline Sunny + silver & $10.1 \mathrm{~b}$ & $27.3 \mathrm{~b}$ & $2.14 \mathrm{a}$ & $0.06 \mathrm{a}$ & $6 \mathrm{~b}$ & $0.82 \mathrm{a}$ & $26 \mathrm{a}$ \\
\hline Steven + black & $10.8 \mathrm{~b}$ & $53.8 \mathrm{a}$ & $2.16 \mathrm{a}$ & $0.08 \mathrm{a}$ & $13 \mathrm{a}$ & $0.13 \mathrm{~b}$ & $10 \mathrm{~b}$ \\
\hline
\end{tabular}

${ }^{\mathrm{v}}$ Means in columns followed by different letters significantly different using least significant difference tests $(P<0.05)$ within significant main plot, subplot, and sub-subplot treatment effects $(P<0.05$, except $P<0.1$ for harvest ELISA).

${ }^{\mathrm{w}}$ Early = transplanted 24 March, late $=4$ May, untreated $=$ no insecticide, foliar $=$ treated with foliar insecticide, soil $=$ treated with imidacloprid as a soil drench, black = black plastic mulch, silver = silver-painted black plastic mulch, Sunny = cv. Sunny Hybrid, and Steven = cv. Stevens.

${ }^{x}$ Subset of total thrips per 10 blossoms.

y Analysis using ELISA values

${ }^{\mathrm{z}}$ Percent positive TSWV, analysis using number of ELISA-positive samples 
in 1997 (early $=17 \%$, late $=29 \%$, df $=1, F$ $=4.0, P=0.05)$ and for the seasonal ELISA means in 1998 (Table 2). Also, reductions in ELISA-positive samples due early planted tomato in both 1997 (91\%, Table 1) and 1998 (89\%, Table 3) than in late-planted tomato (57 and $86 \%$, respectively). The incidence of TSWV varied significantly between treatments in both years, but the analysis of variance using the actual ELISA values provided a different separation of means than using percent TSWV-positive plants (Tables 1 and 2). The lower incidence of ELISA-positive samples in early planted than in late planted tomatoes in both years (Tables 1 and 2) could be related to the lower incidence of viruliferous thrips early in the spring than late spring at Tifton $(H$. R. Pappu, unpublished data). In any case, it to treatment effects tended to be greater in

was apparent that even though the late planting date avoided thrips, it did not avoid transmission of TSWV. The overall percentage of TSWV-positive plants by ELISA was not different between symptomatic and asymptomatic plants at harvest, $10 \pm 3 \%$ (STDERR, $n=71$ ) and $11 \pm 4 \%$ $(n=72)$ in 1997 and $22 \pm 3 \%(n=144)$ and $22 \pm 3 \%(n=144)$ in 1998 , respectively, suggesting that there were as many TSWVinfected, asymptomatic plants as symptomatic plants by the end of the season.

Data from 1997 and 1998 indicated that intensive insecticide use could result in an approximately $50 \%$ increase in weight of marketable tomato fruit over the untreated control (Tables 4 and 5). The insecticide effect was attributed mainly to thrips control, because the incidence of other insect pests in the spring was low and only thrips were consistently present throughout the

Table 3. Main (planting date)-subplot (insecticide) treatment interactions for Frankliniella occidentalis, enzyme-linked immunosorbent assay (ELISA) values indicative of Tomato spotted wilt virus infection at harvest, and tomato fruit yield at Tifton, GA in $1998^{\mathrm{v}}$

\begin{tabular}{lccccc}
\hline & Foccidentalis & & \multicolumn{2}{c}{ Marketable } & \\
\cline { 2 - 2 } Treatment $^{\mathbf{w}}$ & Per blossom & ELISA harvest & Total no. & Total wt. (lbs) & Value (\$) \\
\hline Early untreated & $4.0 \mathrm{a}$ & $0.44 \mathrm{~b}$ & $64 \mathrm{c}$ & $17 \mathrm{c}$ & $4,147 \mathrm{c}$ \\
Early foliar & $4.6 \mathrm{a}$ & $1.31 \mathrm{a}$ & $80 \mathrm{~b}$ & $24 \mathrm{~b}$ & $5,854 \mathrm{~b}$ \\
Early soil + foliar & $2.4 \mathrm{~b}$ & $0.15 \mathrm{c}$ & $111 \mathrm{a}$ & $34 \mathrm{a}$ & $8,294 \mathrm{a}$ \\
Late untreated & $1.6 \mathrm{a}$ & $0.80 \mathrm{a}$ & $25 \mathrm{~b}$ & $7 \mathrm{~b}$ & $1,708 \mathrm{~b}$ \\
Late foliar & $0.3 \mathrm{~b}$ & $0.45 \mathrm{~b}$ & $25 \mathrm{~b}$ & $7 \mathrm{~b}$ & $1,708 \mathrm{~b}$ \\
Late soil + foliar & $0.5 \mathrm{~b}$ & $0.11 \mathrm{c}$ & $45 \mathrm{a}$ & $14 \mathrm{a}$ & $3,415 \mathrm{a}$ \\
Interaction $P>F^{\mathrm{z}}$ & 0.06 & 0.11 & 0.06 & 0.07 & 0.07 \\
LSD at $P<0.05$ & 1.28 & 0.28 & 13.9 & 5.40 & 1,317 \\
\hline
\end{tabular}

${ }^{v}$ Means in columns followed by the same letter within early or late manipulates are not significantly different using least significant difference (LSD) tests $(P<0.05$, error $=\sqrt{ }(2 \times$ error of sub/4 $\times 3))$ at the indicated levels of significance for main plot-subplot interactions.

${ }^{\mathrm{w}}$ Early $=$ transplanted 24 March, late $=4$ May, untreated $=$ no insecticide, foliar $=$ treated with foliar insecticide, soil $=$ treated with imidacloprid as a soil drench, black = black plastic mulch, silver $=$ silver-painted black plastic mulch.

$x$ Analysis using ELISA values

${ }^{y}$ Value per 0.4 ha; yield based on 5 plants harvested twice, 4,356 plants per 0.4 ha (acre), \$7/11.3-kg (25-lb) carton.

${ }^{\mathrm{z}}$ Level of significance for the interaction.

Table 4. Main plot (cultivar) and subplot (insecticide, mulch, and planting date) treatment effects on the number, weight, and value of tomato fruit yield at Tifton, GA in 1997x

\begin{tabular}{|c|c|c|c|c|}
\hline \multirow[b]{2}{*}{ Treatment $^{\mathrm{y}}$} & \multicolumn{2}{|c|}{ Marketable fruit } & \multirow{2}{*}{$\begin{array}{c}\text { Unmarketable fruit } \\
\text { Total no. }\end{array}$} & \multirow[b]{2}{*}{ Value $(\$)^{\mathrm{z}}$} \\
\hline & Total no. & Total weight (kg) & & \\
\hline \multicolumn{5}{|l|}{ Main plots } \\
\hline 'Stevens' & $153 \mathrm{a}$ & $27.4 \mathrm{~b}$ & $29.7 \mathrm{a}$ & $3,341 \mathrm{~b}$ \\
\hline 'Sunny Hybrid' & $115 \mathrm{~b}$ & $30.7 \mathrm{a}$ & $34.7 \mathrm{a}$ & $3,740 \mathrm{a}$ \\
\hline \multicolumn{5}{|l|}{ Subplots } \\
\hline Early treated black & $204 \mathrm{a}$ & $45.0 \mathrm{a}$ & $34.3 \mathrm{a}$ & $5,491 \mathrm{a}$ \\
\hline Early treated silver & $190 \mathrm{ab}$ & $44.1 \mathrm{a}$ & $30.4 \mathrm{ab}$ & $5,378 \mathrm{a}$ \\
\hline Early treated bare & $171 \mathrm{abc}$ & $40.3 \mathrm{ab}$ & $33.6 \mathrm{a}$ & $4,916 \mathrm{ab}$ \\
\hline Early check silver & $163 \mathrm{bc}$ & $36.5 \mathrm{bc}$ & $40.6 \mathrm{a}$ & $4,458 \mathrm{bc}$ \\
\hline Early check bare & $157 \mathrm{bc}$ & $31.8 \mathrm{~cd}$ & $26.5 \mathrm{ab}$ & $3,883 \mathrm{~cd}$ \\
\hline Early check black & $146 \mathrm{c}$ & $29.3 \mathrm{~d}$ & $38.8 \mathrm{a}$ & $3,573 \mathrm{~d}$ \\
\hline Late treated silver & $74 \mathrm{~d}$ & $15.0 \mathrm{e}$ & $30.5 \mathrm{ab}$ & $1,829 \mathrm{e}$ \\
\hline Late treated black & $62 \mathrm{~d}$ & $12.3 \mathrm{ef}$ & $37.3 \mathrm{a}$ & 1,504 ef \\
\hline Late check black & $37 \mathrm{~d}$ & $6.8 \mathrm{f}$ & $17.9 \mathrm{~b}$ & $835 \mathrm{f}$ \\
\hline
\end{tabular}

${ }^{\mathrm{x}}$ Means followed by different letters significantly different using least significant difference tests $(P<$ $0.05)$ within significant main plot and subplot treatment effects $(P<0.05)$.

${ }^{\mathrm{y}}$ Early $=$ transplanted 7 April, late $=7$ May, check $=$ untreated with insecticide, treated $=$ treated with insecticide, black $=$ black plastic mulch, bare $=$ bare soil, and silver $=$ silver-painted black plastic mulch.

${ }^{\text {z } V a l u e ~ p e r ~} 0.4$ ha; yield based on 5 plants harvested twice, 4,356 plants per 0.4 ha (acre), $\$ 7 / 11.3-\mathrm{kg}$ (25-lb) carton. test. Even though later planted tomato avoided thrips, this tactic did not help reduce the incidence of plants infected with TSWV and generally resulted in reduced yields in both 1997 and 1998 (early marketable weight $=37.8$, late $=11.4, \mathrm{df}=1$, $F=250, P=0.0001$ and Table 5, respectively). The reduced yields, even in the best treatments, could be due to climatic factors (high temperature, reduced fruit set, and increased blossom end rot). Lower yields with late planting coincides with dramatic price reductions in the Georgia tomato market that historically occurs at the end of June (9); therefore, late planting is currently not a viable option for springgrown tomato in this area.

In 1998, the percentage of regularly ripened fruit two weeks after harvest varied significantly among treatment plots (Table $5)$. The early planted tomato and the intensive insecticide treatment with the imidacloprid applied to the soil had the greatest percentages of regularly ripened fruit. Imidacloprid also increases regular ripening by reducing irregular ripening caused by whitefly damage (16). The impact on quality of tomato fruit with respect to ripening can be as important as yield and emphasizes the effectiveness of the early plant, intensive insecticide treatments.

Overall, insecticide treatments consistently reduced thrips and the incidence of spotted wilt disease and increased marketable fruit yields, regardless of planting date, in both years $(1997$, treated $=35.4$, untreated $=26.1, \mathrm{df}=1, F=30.9, P=$ 0.0001 , and 1998, Table 2). The silver reflective mulch tended to reduce thrips and incidence of TSWV (based on TSWVpositive samples), but did not result in increased yields in either year (1997, df = $1, F=2.41, P=0.13$, or 1998 , Table 5), possibly due to other factors. Soil temperature could be affected by mulch color (20); therefore, making the outside shoulders of the plastic mulch bed more reflective and allowing the plastic row center to remain black could increase soil warming. Similarly, the TSWV-resistant tomato cultivar, Stevens, had fewer thrips and less TSWV, but was not competitive with marketable weight of Sunny Hybrid tomato in either year (1997, Sunny Hybrid $=30.7$, Stevens $=27.4$, df $=1, F=10.1, P=0.05$, or 1998, Table 5).

Tomato yields can respond to specific control tactics targeted at thrips to reduce the effect of TSWV. The response to thrips control may not be practical given the intensity of treatments, but some conclusions can be drawn from these data. First, use of a late planting date to avoid thrips and TSWV did not appear to be a viable option in the spring in south Georgia. Second, intensive insecticide treatments for thrips control resulted in increased marketable yields and reduced percent irregular ripening, regardless of planting date. Thus, insecticide treatment can be a viable tactic, 
Table 5. Main plot (date), subplot (insecticide), and sub-subplot (cultivar, mulch) treatment effects on the tomato yield at Tifton, GA in $1998^{\mathrm{x}}$

\begin{tabular}{|c|c|c|c|c|c|}
\hline \multirow[b]{2}{*}{ Treatment $^{y}$} & \multicolumn{2}{|c|}{ Marketable fruit } & \multirow{2}{*}{$\begin{array}{c}\text { Unmarketable fruit } \\
\text { Total no. }\end{array}$} & \multirow[b]{2}{*}{ Regular ripened fruit $(\%)$} & \multirow[b]{2}{*}{ Value $(\$)^{z}$} \\
\hline & Total no. & Total weight (kg) & & & \\
\hline \multicolumn{6}{|l|}{ Main plots } \\
\hline Early & $85 \mathrm{a}$ & $25 \mathrm{a}$ & $60 \mathrm{~b}$ & $45 \mathrm{a}$ & $6,066 \mathrm{a}$ \\
\hline Late & $31 \mathrm{~b}$ & $10 \mathrm{~b}$ & $87 \mathrm{a}$ & $14 \mathrm{~b}$ & $2,307 \mathrm{~b}$ \\
\hline \multicolumn{6}{|l|}{ Subplots } \\
\hline Untreated & $44 \mathrm{~b}$ & $12 \mathrm{~b}$ & $67 \mathrm{ab}$ & $26 \mathrm{~b}$ & $2,937 \mathrm{~b}$ \\
\hline Foliar & $52 \mathrm{~b}$ & $16 \mathrm{~b}$ & $86 \mathrm{a}$ & $25 \mathrm{~b}$ & $3,806 \mathrm{~b}$ \\
\hline Foliar + soil & $78 \mathrm{a}$ & $24 \mathrm{a}$ & $66 \mathrm{~b}$ & $41 \mathrm{a}$ & $5,816 a$ \\
\hline \multicolumn{6}{|l|}{ Sub-subplots } \\
\hline Sunny + black & $69 \mathrm{a}$ & $20 \mathrm{a}$ & $72 \mathrm{a}$ & $29 a$ & $4,992 \mathrm{a}$ \\
\hline Sunny + silver & $62 \mathrm{a}$ & $18 \mathrm{a}$ & $68 \mathrm{a}$ & $33 \mathrm{a}$ & $4,492 \mathrm{a}$ \\
\hline Steven + black & $44 \mathrm{~b}$ & $13 \mathrm{~b}$ & $79 a$ & $30 \mathrm{a}$ & $3,076 \mathrm{~b}$ \\
\hline
\end{tabular}

${ }^{x}$ Means in columns followed by different letters significantly different using least significant difference tests $(P<0.05)$ within significant main plot, subplot, and sub-subplot treatment effects $(P<0.05$, except $P<0.1$ for total no. unmarketable).

${ }^{\text {y }}$ Early = transplanted 24 March, late $=4$ May, untreated = no insecticide, foliar $=$ treated with foliar insecticide, soil $=$ treated with imidacloprid as a soil drench, black = black plastic mulch, silver = silver-painted black plastic mulch, Sunny = cv. Sunny Hybrid, and Steven = cv. Stevens.

${ }^{\mathrm{z}}$ Value per 0.4 ha; yield based on 5 plants harvested twice, 4,356 plants per 0.4 ha (acre), \$7/11.3-kg (25-lb) carton.

but the intensity of insecticide treatment could lead to insecticide resistance for western flower thrips (7) and other thrips species. We believe that an insecticide program needs to be carefully developed with the proper timing relative to plant age, efficacy, and application methods to be an effective option for commercial tomato growers. Some of these factors are under investigation. Finally, both silvered (reflective) plastic mulch and the resistant Stevens affect the incidence of thrips and TSWV, but did not have the desired effects on tomato yield. Other UV-reflective mulches (22) and newer tomato TSWVresistant cultivars could potentially increase the impact of these management tactics on tomato yield.

\section{ACKNOWLEDGMENTS}

We thank the University of Georgia, Coastal Plain Experiment Station for assistance in data analysis, manuscript reviews, and publication costs; J. Davis, D. Cook, and T. Stone for their assistance in sampling and identifying the thrips; K. Lewis and W. Tillery for conducting ELISA; and J. W. Todd for advice and technical assistance in the identification of thrips.

\section{LITERATURE CITED}

1. Bertrand, P. F. 1997. 1996 Georgia Plant Disease Losses. Univ. Ga. Coop. Ext. Serv., Athens, GA.

2. Brown, S. L., Todd, J. W., Culbreath, A. K., Baldwin, J., Beasley, J., and Pappu, H. 1999. Tomato spotted wilt of peanut: Identifying and avoiding high-risk situations. Pages 24-30 in: 1999 Peanut Update, Univ. Ga. Coop. Ext. Serv., Athens, GA.

3. Csizinszky A. A., Schuster, D. J., and Kring, J. B. 1995. Color mulches influence yield and in- sect pest populations in tomato. J. Am. Soc. Hortic. Sci. 120:778-784.

4. Culbreath, A. K., Todd, J. W., Brown, S. L., Baldwin, J. A., and Pappu, H. R. 1999. A genetic and cultural package for management of tomato spotted wilt virus in peanut. Biol. Cult. Tests 14:1-8.

5. Eger, J. E., Stavisky, J., and Funderburk, J. E. 1998. Comparative toxicity of spinosad to Frankliniella spp. (Thysanoptera: Thripidae), with notes on a bioassay technique. Fla. Entomol. 81:547-551.

6. Greenough, D. R., Black, L. L., and Bond, W. P. 1990. Aluminum-surfaced mulch: an approach to the control of tomato spotted wilt virus in solanaceous crops. Plant Dis. 74:805808 .

7. Kontsedalov, S. Weintraub, P. G., Horowitz, A. R., and Ishaaya, I. 1998. Effects of insecticides on immature and adult western flower thrips (Thysanoptera: Thripidae) in Israel. J. Econ. Entomol. 91:1067-1071.

8. Kumar, N. K. K., Ullman, D. E., and Cho, J. J. 1995. Resistance among Lycopersicon species to Frankliniella occidentalis (Thysanoptera: Thripidae). J. Econ. Entomol. 88:1057-1065.

9. Mizelle, W. O. 1995. Vegetable economics. Univ. Ga. Coop. Ext. Serv. Agric. Econ. 91013. Athens, GA

10. Mizelle, W. O. 1997. Vegetable acreage estimates. Univ. Ga. Coop. Ext. Serv. Agric. Econ. 93-027. Athens, GA.

11. Moyer, J. W. 1999. Tospoviruses (Bunyaviridae). Pages 1803-1807 in: Encyclopedia of Virology. A. Granoff and R. G. Webster, eds. Academic Press, San Diego, CA.

12. Mumford, R. A., Barker, I., and Wood, K. R. 1996. The biology of the tospoviruses. Ann. Appl. Biol. 128:159-183.

13. Oetting, R. D., Beshear, R. J., Liu, T. X., Braman, S. K., and Baker, J. R. 1993. Biology and identification of thrips on greenhouse ornamentals. Ga. Agric. Exp. Stn. Res. Bull. 414.

14. Pappu, H. R. 1997. Management of emerging virus threats of crops: Impact of biotechnology in controlling tospoviruses. Biotechnol. Dev. Monit. 31:14-17.

15. Peters, D., and Goldbach, R. 1995. The biology of tospoviruses. Pages 199-210 in: Pathogenesis and Host Specificity in Plant Diseases. Vol. III. Viruses \& Viroids. R. P. Singh, U. S. Singh, and K. Kohmoto, eds. Pergamon Press, Oxford, U.K.

16. Powell, C. A., and Stoffella, P. J. 1998. Control of tomato irregular ripening with imidacloprid. HortScience 33:283-284.

17. Salguero-Navas, V. E. 1990. Sampling programs and ecological relationships of Frankliniella spp. on tomato. Ph.D. dissertation, Univ. Fla. Gainesville.

18. Salguero Navas, V. E., Funderburk, J. E., Beshear, R. J., Olson, S. M., and Mack, T. P. 1991 Seasonal patterns of Frankliniella spp. (Thysanoptera: Thripidae) in tomato flowers. J. Econ. Entomol. 84:1818-1822.

19. SAS Institute. 1990. SAS user's guide, version 6, SAS Institute, Cary, NC.

20. Schmidt, J. R., and Worthington, J. W. 1998. Modifying heat unit accumulation with contrasting colors of polyethylene mulch. HortScience 33:210-214.

21. Stannard, L. J. 1968. The Thrips, or Thysanoptera of Illinois. Ill. Nat. Hist. Surv. Bull Vol. 29 Article 4, Urbana.

22. Terry, L. I. 1997. Host selection, communication and reproductive behaviour. Pages 65-118 in: Thrips as Crop Pests. T. Lewis, ed. CAB International, New York.

23. Todd, J. W., Culbreath, A. K., and Brown, S. L. 1996. Dynamics of vector populations and progress of spotted wilt disease relative to insecticide use in peanuts. Acta Hortic. 431:483-490.

24. Ullman, D. E., Sherwood, J. L., and German, T. L. 1997. Thrips as vectors of plant pathogens. Pages 539-564. in: Thrips as Crop Pests. T. Lewis, ed. CAB International, New York.

25. Webb, S. E., Kok-Yohomi, M. L., and Tsai, J. H. 1997. Evaluation of Frankliniella bispinosa as a potential vector of tomato spotted wilt virus. (Abstr.) Phytopathology 87(Suppl.):S102. 